\title{
Microscopic Marine Organisms in the Service of Hydrography.*
}

\author{
By \\ Professor P. T. Cleve, \\ University of Upsala.
}

IT has for a long time been known that the sea abounds in microscopic organisms, both animal and vegetable. Among the former are entomostraca, infusoria, radiolarians, foraminifera, as well as larvæ of mollusca, radiates, and bryozoa. Among the plant-life the mass consists of diatoms, cilioflagellates, flagellates, and certain unicellular chlorophyllaceous algæ. For these pelagic forms Prof. Hensen has proposed the name plankton, which has been universally accepted.

Some years ago I examined the samples of vegetable plankton collected by the Swedish Arctic expeditions, as well as samples from various parts of the tropical seas, and I became convinced that certain parts of the oceans are characterised by different species. In the year 1893 I spent the summer at the west coast of Sweden, where I had the opportunity of examining the plankton at the marine biological station of Christineberg; that is to say, in a fjord (loch) called Gullmarsfjord. I found that in the month of June the plankton consisted mainly of cilioflagellates, Ceratium tripos being the most common. During the last days of the month, however, the plankton changed. The water was from that time very rich in entomostraca, and the cilioflagellates became less abundant. At the same time the mackerel appeared in the fjord. All my samples had been collected at the mouth of the fjord, where the water is not very deep. In the interior the fjord becomes deeper, as is the case also with the Scotch lochs, and I now wished to know the character of the plankton at different depths. What I hitherto had examined was the plankton of the current, called by the Swedish hydrographers the Baltic current, which in the spring and summer runs along the Scandinavian coast up to Bergen, in Norway. Below that surface current there exists, according to the Swedish hydrographers, water with lower temperature and greater salinity. In

* Reprinted from Nature, vol. 1v. No. 1413. 
company with Prof. G. Théel, and with the aid of his net, which could be closed and opened below the water, I made in July an attempt to get plankton from different depths of the fjord. We found in the cold bottom-water very little plankton, some few specimens of a large Sagitta and of Calanus finmarchicus only. At about 30-40 metres the cilioflagellates (among them Ceratium divergens) were abundant, and on the surface the entomostraca. This examination was repeated during the first days of August, when I and Dr. Aurivillius had the opportunity of accompanying Prof. Pettersson and Mr. G. Ekman on the hydrographical expedition which went out at the time. The result was the same as before; but from the determination of the temperature and the salinity of the water, it became clear that the plankton had been collected in water differing in those respects, and consequently that the different strata of water were characterised by different amounts of plankton, and by different species. Samples of plankton were afterwards collected by the Swedish hydrographical expeditions at the same time as samples of water for physical and chemical research. The examination of the plankton was carried out by Dr. Aurivillius, who took charge of the animal plankton, and by myself, who undertook the vegetable.

Having examined a large number of samples, I have lately found that the plankton of the Skagerack and Kattegat can be classed according to the prevailing species, and in this way I distinguished four types, namely: (1) Tripos-plankton, (2) Didymus-plankton, (3) Tricho-plankton, and (4) Sira-plankton.

(1) The Tripos-plankton is characterised by its scarcity in diatoms, and its abundance in cilioflagellates and entomostraca, which give to the spirit, in which the samples are preserved, an orange or yellow colour, all the other kinds of plankton colouring it more or less deep green. Among the entomostraca, according to the publications of Dr. Aurivillius, Paracalanus parvus, Pseudocalanus elongatus, and Evadne spinifer $a$ are the most abundant. Among the cilioflagellates Ceratium tripos, with the variety macroceros, is the most common. C. divergens, C. furca, and $C$. fusus occur in less numbers. Diatoms are, as I have said, scarce, the most abundant being Coscinodiscus concinnus and Rhizosolenia gracillima. In winter and early spring the unicellular alga, Halosphaera viridis, is found in abundance. This kind of plankton characterises the water of the Baltic current, and prevails in the summer in the Kattegat and Skagerack. The organisms consist chiefly of euryheline and eurythismic species, which can withstand the dilution of the salter North Sea water by the slightly saline Baltic water.

It seems very probable that this first type of plankton may by future researches be split up into different kinds. We may thus, perhaps, 
distinguish one kind, characterised by Halosphaera viridis, and occurring in the winter; another by Rhizosolenia gracillima, occurring in the summer; one with Paracalanus parvus, and another with Pseudocalanus elongatus, and so on.

In all cases it seems to be certain that the water containing this first type is derived from the North Sea as well as from the Baltic.

(2) The Didymus-planteton consists principally of diatoms, among which the most characteristic species are Chaetoceros curvicetus, Ch. didymus, Ditylum Brightwellii, Rhizosolenia alata, and gracillima (the latter probably a residuum of Type, 1), Skeletonema costatum and Thalassiothrix Frauenfeldii (the latter probably common to Type 3). A silicoflagellate, Dictyocha speculum, occurs constantly, but not abundantly. The cilioflagellates, as well as the entomostraca, are scarce.

This kind of plankton was predominant in the Skagerack and Kattegat in November, 1893, filling the fjords from the bottom to the surface. With the water containing this kind of plankton the herring arrived on the shores of Scandinavia. It seems to have been a very large bulk of water that at this time set in to the coast, as it drove away the whole of the summer water from bottom to surface.

The diatoms of this type are not known from the Arctic Ocean or from the Northern Atlantic, but are well known from the coasts of France and Belgium and the English Channel. It seems thus to be beyond doubt that the water came from the southern North Sea, along the western coast of Denmark. The temperature, as well as the salinity, were found to be variable, but the plankton constant. In the Gullmarsfjord the water at the surface had a temperature of $7^{\circ} \mathrm{C}$., at a depth of $30 \mathrm{~m}$. nearly $12^{\circ}$, and at the bottom only $4^{\circ}$ to $5^{\circ}$. The salinity amounted respectively to about $26-27,32$ and 33 to 37 per thousand. This variation may be explained by the mixture of the water of the second type with the water previously present in the Kattegat. Probably the warmest water was the most pure water of Type 2, and corresponds to one of the kinds of water called by the Swedish hydrographers the bank-water.

(3) The third type of plankton, the Tricho-plankton, is distinguished by its diatoms, especially the following species: Thalassiosira longissima, Rhizosolenia styliformis, Chaetoceros atlanticus (in a less degree also by Ch. borealis and its variety Brightwellii), and Biddulphia mobilensis. The first-named species occur abundantly and almost pure in the Northern Atlantic, south of Iceland; the last-named I observed at Plymouth, West Scotland, and in the North Sea. This plankton may thus be considered a Northern Atlantic plankton. At the Scandinavian coast it seems to occur very rarely in a pure state; in fact, I have seen 
it only once, in February of this year, gathered at the bottom of the Christiania fjord $\left(100 \mathrm{~m}\right.$.), where the temperature amounted to $7 \cdot 5^{\circ} \mathrm{C}$., and the salinity to $34-76$ per thousand, the highest figures obtained by the hydrographical examinations of all the samples gathered in February, 1896.

On the other hand, this plankton was frequently found mixed with the next type in samples collected at the time named.

(4) The fourth type, the Sira-planteton, consists also mainly of diatoms, but of different species, the most characteristic being Thalassiosira Nordenstiöldii and Th. gravida, Chaetoceros graenlandicus, Ch. socialis, Ch. scolopendra, Ch. teres, Nitschia seriata, many of which belong to the Arctic seas, and some of which are new to science. Among the cilioflagellates the most abundant is a variety arctica of Ceratium tripos, distinguished by Dr. Aurivillius as a constituent of the plankton of Baffin's Bay.

There can be no doubt about the Arctic origin of this type. It occurred in the Skagerack and Kattegat this year in February and March, always more or less mixed with (3) and (1). In the Skagerack the water with Types (3) and (4) was covered by a shallow layer of water with Type (1); but in the Kattegat it reached the surface. The admixture of Type (3) shows that the water on or before its arrival at the coast of Sweden was mixed with Atlantic water. The temperature and the salinity were found to vary greatly, owing to the admixture of the slightly saline Baltic water, at this time of the year very cold.

I have observed the same type of water in some slides collected on the west coast of Scotland by Mr. George Murray, and sent to me by Mr. Grove. These samples had been gathered in the spring of 1888-a year remarkable in England as an unusually cold one.

As far as the plankton researches are advanced at present we may conclude that the surface-water around the Swedish coast consists in the summer of water from the North Sea mixed with Baltic water; that in the autumn its place is taken by water from the southern part of the North Sea; and in the winter by water from the Northern Atlantic and the Arctic Ocean. Whether these changes occur regularly every year, or in certain years only, cannot be answered for the moment. Probably the last change is in correspondence, as Professor Petersen has recently suggested, with variations in the amount of water which the Gulf Stream carries past Iceland, westwards to Davis Strait, and eastwards to the Arctic Ocean.

I think I have proved by the above that the examination of plankton is a matter of the greatest interest, not only in relation to hydrography, but also to meteorology and to fishery questions. There can be no doubt 
about the close connection between the state of the sea and the movements of the air, and the still obscure causes of the migration of fishes may be found to be intimately connected with the change of water containing different kinds of plankton.

It is thus an important matter that the plankton of the North Sea should be thoroughly and systematically examined; but for this, international co-operation of all the nations around the North Sea is required. I imagine that a central station, under the direction of competent persons and provided with adequate accommodation, might be erected. Samples could be collected at certain intervals, and by the same kind of apparatus at different stations, and sent to the central one for examination. The details should be published every month, and the general results formulated in a way that would be useful to hydrographers, meteorologists, etc. The marine biological stations already in existence will probably be found willing for co-operation in such an undertaking; but they will be able to collect plankton only near the shores, or at short distances from them. For getting samples from the open seas, the officers of the steamers crossing the North Sea and the Northern Atlantic might be found willing to assist, as the plankton may, as Dr. John Murray hinted to me, be procured by pumping water into a silk net. I recently tried this method whilst crossing from Edinburgh to Göttenburg. I fastened the net to the pump when the deck was being washed, and in this way I obtained sufficient plankton to prove that in the last days of July the North Sea was almost free from diatoms, and its plankton consisted mainly of cilioflagellates and entomostraca. 


\title{
The Regulations of the Local Sea Fisheries Committees in England and Wales.
}

\author{
By
}

E. J. Allen, B.Sc., Director of the Plymouth Laboratory.

The powers conferred on the Board of Trade, under the Sea Fisheries Regulation Act of 1888, to create, upon the application of a County or Borough Council, a local Fisheries District, and to provide for the constitution of a Local Fisheries Committee for the regulation of the sea fisheries carried on within the district, have been requisitioned by the majority of the Councils of the maritime counties of England and Wales, and at the present time Fisheries Districts and Fisheries Committees are constituted around nearly the whole coast line, the Committees having jurisdiction over all fishing carried on within the three-mile limit. The only portion of coast still unprovided for is that which lies in the counties of Norfolk and Suffolk, between Happisburg and Dovercourt.

The following is a list of the Fisheries Districts, with their boundaries, as they now exist:-

Northumberland-from the boundary between England and Scotland to the river Tyne.

North-EAStern-from the river Tyne to Donna Nook Beacon, on the coast of Lincolnshire.

EAstern-from Donna Nook Beacon to Happisburg, on the coast of Norfolk.

Between Happisburg in Norfolk and Dovercourt in Essex no Fisheries District has been established.

Kent and Essex-from Dovercourt in Essex to Dungeness.

Sussex-from Dungeness to Hayling Island.

Southern-from Hayling Island to the western boundary of Dorset. 